\title{
ANTIGENICITY OF POLYPEPTIDES (POLY ALPHA AMINO ACIDS)*
}

\section{Immunological Studies with a New Group of Synthetic COPOLYMERS}

\author{
By PaUl H. Maurer, 8 Ph.D., Bernard F. Gerulat, Ph.D., and \\ PAUL PINCHUCK, Pr.D. \\ (From the Microbiology Department, Seton Hall College of Medicine and Dentistry, \\ Jersey City)
}

(Received for publication, March 3, 1964)

Previous reports from this laboratory have dealt with observations on the immunogenicity in rabbits (1-5), guinea pigs $(6,7)$, and man (8) of synthetic random copolymers consisting of 2 and $3 \mathrm{~L}-\alpha$-amino acids. In the rabbit studies, the copolymers consisting of the amino acids, glutamic acid and alanine, in a ratio of $60: 40\left(\mathrm{G}_{60} \mathrm{~A}_{40}\right)^{1}$ and the terpolymer consisting of the latter amino acids and lysine $\left(\mathrm{G}_{42} \mathrm{~L}_{23} \mathrm{~A}_{30}\right)$ were very effective antigens and have repeatedly been so in our laboratory. This latter terpolymer has also been found to be highly antigenic in guinea pigs (7), man (8), and mice (9). The experiments presented in this report on the immunogenicity of a new group of polymers were undertaken to learn: (a) whether polymers consisting of other ratios of glutamic acid and alanine or glutamic acid and other amino acids are effective antigens; $(b)$ the possible basis for the enhanced immunogenicity of $\mathrm{G}_{42} \mathrm{~L}_{28} \mathrm{~A}_{30}$. When negative or poor responses were noted with the polymers in rabbits, the material was then tested in guinea pigs. This report will present the findings on the immunogenicity of the preparations and a subsequent publication will present the quantitative relationships among the various polymers and their antisera.

\section{Materials and Methods}

\section{Materials.-}

Table I lists the random polymers studied. The methods employed in preparing the polymers from the $N$-carboxy $\alpha$-amino acid anhydrides, their characterization and the techniques

\footnotetext{
* This work was supported by Grants AI 3514 and 2AI 196 from the National Institute of Allergy and Infectious Diseases and Contract No. DA-49-193-MD-2113 from the Department of the Army, Office of the Surgeon General.

† Presented in part at the annual meeting of the American Association of Immunologists, Atlantic City, New Jersey, April, 1963.

$\S$ Research Career Investigator of National Institute of Allergy and Infectious Diseases.

${ }^{1}$ In this article, G, L, A, V, and Leu stand for the amino acids glutamic acid, lysine, alanine, valine, and leucine. Subscripts refer to mol per cent amino acid in the polymer.
} 
for immunizing rabbits and guinea pigs have been referred to in the previous publications $(1-8)$.

TABLE I

Synthetic Polymers of L- $\alpha$-Amino Acids Studied for Antigenicity

\begin{tabular}{|c|c|c|}
\hline Copolymer* & Nomenclature employed & $\begin{array}{l}\text { Approximate average } \\
\text { mol. wt. }\end{array}$ \\
\hline Glu $_{90}$ ala $_{10}$ & $\mathrm{G}_{90} \mathrm{~A}_{10}$ & 75,000 \\
\hline Glu $_{75}$ ala $_{25}$ & $\mathrm{G}_{75} \mathrm{~A}_{25}$ & 50,000 \\
\hline Glu $_{60}$ ala $_{40} \neq$ & $\mathrm{G}_{60} \mathrm{~A}_{40}$ & 33,000 \\
\hline Glu $_{40}$ ala $_{60}$ & $\mathrm{G}_{40} \mathrm{~A}_{60}$ & 30,000 \\
\hline Glu $_{75} \mathrm{val}_{25}$ & $\mathrm{G}_{75} \mathrm{~V}_{25}$ & 150,000 \\
\hline Glu $_{80}$ leuc $_{20}$ & $\mathrm{G}_{80} \mathrm{Leu}_{20}$ & 89,000 \\
\hline Lys $_{70 a_{3}}$ & $\mathrm{~L}_{70} \mathrm{~A}_{30}$ & 85,000 \\
\hline Glu $_{54}$ lys $_{36}$ ala $_{10}$ & $\mathrm{G}_{64} \mathrm{~L}_{36} \mathrm{~A}_{10}$ & 70,000 \\
\hline Glu $_{48}$ lys $_{32}$ ala $_{20}$ & $\mathrm{G}_{48} \mathrm{~L}_{32} \mathrm{~A}_{20}$ & 55,000 \\
\hline Glu $_{42}$ lys $_{28}$ ala $_{30} \ddagger$ & $\mathrm{G}_{42} \mathrm{~L}_{28} \mathrm{~A}_{30}$ & 65,000 \\
\hline Glu $_{24}$ lys $_{16}$ ala $_{60}$ & $\mathrm{G}_{24} \mathrm{~L}_{16} \mathrm{~A}_{60}$ & 28,000 \\
\hline
\end{tabular}

* Subscript refers to mol per cent of amino acid in polymer.

$\ddagger$ Immunogenicity of these polymers discussed in references 3 and 5 .

Methods.-

Immunization.-New Zealand white rabbits weighing between 2.5 and $3 \mathrm{~kg}$ were immunized with the polymers in a complete Freund's adjuvant for three courses as described previously (3). Each rabbit received a total of $60 \mathrm{mg}$ of polymer ( $50 \mathrm{mg}$ adjuvant, $10 \mathrm{mg}$ solution).

Hartley strain white guinea pigs weighing between 300 and $400 \mathrm{gm}$ were also immunized with the polymer in complete adjuvant as described in $(6,7)$. On days 10 to 12 , after the injection of $100 \mu \mathrm{g}$ polymer, the guinea pigs were bled from the retroorbital sinus and then skin-tested with 100,10 , and $1 \mu \mathrm{g}$ of the copolymers. Reactions were read at 4 to 6 and 24 hours. The bleeding and testing were repeated on days 20 to 25 . The animals were boosted with another $100 \mu \mathrm{g}$ polymer and the above bleeding and testing repeated. The best reactors were reinjected and exsanguinated 2 to 3 weeks later. All sera were preserved by the addition of 1:10,000 "merthiolate" and kept frozen until studied.

\section{Testing of Sera.-}

Passive Cutaneous Anaphylaxis (PCA).--The PCA test was performed on all sera as described by Ovary (10). One-tenth $\mathrm{ml}$ of undiluted serum or dilutions thereof, were injected intradermally into guinea pigs weighing 200 to $250 \mathrm{gm}$. Three hours later, $1 \mathrm{ml}$ of a solution containing $250 \mu \mathrm{g}$ of the polymer and 0.5 per cent Evans blue dye was injected intravenously. Blueing reactions were recorded 20 minutes later.

Passive Systemic Anaphylaxis.-Guinea pigs weighing $250 \mathrm{gm}$ were injected intraperitoneally with varying amounts of rabbit antisera. Forty-eight hours later, they received an intravenous injection of the polymer and were observed for symptoms of anaphylactic shock.

Agar Diffusion.-The Preer double diffusion in agar technique was employed in screening the sera that were positive by PCA (11). The concentration of polymers added ranged from 1.5 to $40 \mu \mathrm{g} \mathrm{N} / \mathrm{ml}$. Tubes were placed in a cold room and observed for several weeks.

Quantitative Precipitin Studies.-Before use, the sera were defatted and clarified by centrif- 
ugation at 3000 RPM at $0-5^{\circ} \mathrm{C}$ overnight and then Seitz-filtered. The sera were analyzed by the addition of 1 to $10 \mu \mathrm{g}$ antigen $\mathrm{N}$ to $0.5 \mathrm{ml}$ of undiluted serum. This procedure precipitated the maximum amount of antibody. The complete method for analysis of the antigen-antibody precipitates by the micro Folin technique is based on the previously described method (5). When more than $40 \mu \mathrm{g}$ antibody $\mathrm{N}$ were precipitated, more concentrated reagents were used in analyses. ${ }^{2}$

Immunoelectrophoresis.-The techniques described in reference 12 were employed. Glass slides $4 \times 11 \mathrm{~cm}$ were layered with 1.25 per cent Noble agar in sodium barbital buffer ( $\mathrm{pH} 8.2$; $0.04 \mathrm{M}$ ). Rabbit antisera that precipitated with the homologous polymer were placed in the center well and electrophoresis carried out $(200 \mathrm{v}, 50 \mathrm{ma})$ for 3 hours to separate the serum constituents. Rectangular troughs were then cut on both sides of the center well and filled with either the homologous antigen or sheep antibody against rabbit serum albumin and globulins. The slides were placed in containers at $4^{\circ} \mathrm{C}$ for 2 weeks to allow development of antigen-antibody bands. The plates were then washed, dried, and stained with azocarmine or bromphenol blue.

\section{RESULTS}

Copolymers.-Table II presents the data on the antibody responses during the 3 courses of immunization of rabbits as measured by PCA and quantitative precipitin reactions. The table presents the number of reactors as determined by PCA with undiluted serum, and the PCA titer of pools of the sera constituted as indicated in footnotes to Table II. Pools from the first 2 courses of immunization consisted, generally, of 3 weekly bleedings and course III consisted of an exsanguination bleeding.

In general, the same serum pools that were positive by PCA were tested by the quantitative precipitin reaction with the exception of the $G_{76} A_{25}$, GLeu, and GV sera where, because of the poor responses, only 3,1 , and 3 sera respectively constituted the pools analyzed for precipitins. The results with the copolymers of glutamic acid and another amino acid $\left(\mathrm{G}_{90} \mathrm{~A}_{10}, \mathrm{G}_{75} \mathrm{~A}_{25}, \mathrm{G}_{40} \mathrm{~A}_{60}\right.$, $\mathrm{G}_{75} \mathrm{~V}_{25}, \mathrm{G}_{80} \mathrm{Leu}_{20}$ ) indicate that all of these, with the exception of $\mathrm{G}_{40} \mathrm{~A}_{60}$, are much weaker antigens in rabbits than $\mathrm{G}_{60} \mathrm{~A}_{40}$ which has consistently been a good antigen. Results reported previously (3) and confirmed repeatedly in our laboratory indicated that 80 to 100 per cent of rabbits injected with $\mathrm{G}_{60} \mathrm{~A}_{40}$ react during the first course of immunization, and almost 100 per cent by the third course. The PCA titers of the hyperimmune anti- $\mathrm{G}_{60} \mathrm{~A}_{40}$ sera average about 1:2000 and the antibody levels are a minimum of 100 to $150 \mu \mathrm{g} \mathrm{Ab} \mathrm{N} / \mathrm{ml}$ serum. Similar results are reported here with the $\mathrm{G}_{40} \mathrm{~A}_{60}$ polymer. Of the few reactors against $\mathrm{G}_{90} \mathrm{~A}_{10}, \mathrm{G}_{75} \mathrm{~A}_{25}, \mathrm{G}_{75} \mathrm{~V}_{25}$, and $\mathrm{G}_{80} \mathrm{Leu}_{20}$ even after repeated immunization, the PCA titers were very low (1:10 to $1: 100)$ and the $\mu \mathrm{g}$ antibody $\mathrm{N}$ per $\mathrm{ml}$ serum were as follows: $\mathrm{G}_{75} \mathrm{~A}_{25}, 6.4 ; \mathrm{G}_{80} \mathrm{Leu}_{20}, 20.0 ; \mathrm{G}_{80} \mathrm{~V}_{20}, 26.0$. No precipitin measurements could be made with $\mathrm{G}_{90} \mathrm{~A}_{10}$ antisera.

Studies of the antigenicity of $L_{30} A_{30}$ were undertaken to learn whether the

\footnotetext{
${ }^{2}$ The complete procedure will be described in a subsequent publication.
} 
effective antigenicity of $\mathrm{G}_{42} \mathrm{~L}_{28} \mathrm{~A}_{30}$ may, in part, be attributed to LA type of sequences and also to determine whether a highly positively charged copolymer could be immunogenic. Of the 24 rabbits ( $18 \mathrm{New}$ Zealand white and 6 mixed Dutch) immunized and followed for a period of a year, none produced antibody detectable by PCA. The data obtained with some of the sera are shown in

TABLE II Immune Responses in Rabbits against Synthetic Polymers

\begin{tabular}{|c|c|c|c|c|c|c|}
\hline \multirow{3}{*}{ Polymer } & \multicolumn{3}{|c|}{ PCA Response* } & \multicolumn{3}{|c|}{ Ab per ml serum } \\
\hline & \multicolumn{3}{|c|}{ Course No. } & \multicolumn{3}{|c|}{ Course No. } \\
\hline & I & II & III & I & II & III \\
\hline & & & & $\mu g N$ & $\mu g N$ & $\operatorname{mg} N$ \\
\hline $\mathrm{G}_{90} \mathrm{~A}_{10}$ & $1 / 12(10) \S$ & $2 / 12(10) \S$ & $3 / 12(10) \S$ & 0 & 0 & 0 \\
\hline $\mathrm{G}_{75} \mathrm{~A}_{25}$ & $0 / 11$ & $2 / 11(10)$ & $3 / 11(20) \S$ & $\|$ & $\|$ & $6.4 \rrbracket(3)$ \\
\hline $\mathrm{G}_{40} \mathrm{~A}_{60}$ & $9 / 11(200)$ & $10 / 11(1000)$ & $10 / 11(2000)$ & 12.0 & 75.0 & 170.0 \\
\hline $\mathrm{G}_{80} \mathrm{Leu}_{20}$ & $0 / 12$ & $1 / 12(10)$ & $3 / 12(50) \S$ & 0 & 0 & $20.0 \rrbracket(1)$ \\
\hline $\mathrm{G}_{75} \mathrm{~V}_{25}$ & $0 / 12$ & $2 / 12(50)$ & $3 / 12(200) \S$ & 0 & $\|$ & $26.0 \Uparrow(3)$ \\
\hline $\mathrm{L}_{70} \mathrm{~A}_{30}$ & $0 / 24$ & $0 / 24$ & $0 / 24$ & $* *$ & $* *$ & $* *$ \\
\hline $\mathrm{G}_{64} \mathrm{~L}_{36} \mathrm{~A}_{10}$ & $6 / 12(150)$ & $11 / 12(500)$ & $12 / 12(1000)$ & $20.5 \ddagger t$ & 56.0 & 142.0 \\
\hline $\mathrm{G}_{48} \mathrm{~L}_{32} \mathrm{~A}_{20}$ & $10 / 12(75)$ & $12 / 12(250)$ & $12 / 12(500)$ & 63.0 & 141.0 & 142.0 \\
\hline $\mathrm{G}_{24} \mathrm{~L}_{16} \mathrm{~A}_{60}$ & $12 / 12(200)$ & $12 / 12(500)$ & $12 / 12(1000)$ & 60.0 & 63.0 & 145.0 \\
\hline
\end{tabular}

* Figure for each course presented as the number of reactors and values in parenthesis refer to the average PCA titer of pools made of reactors plus non-reactors unless indicated otherwise by footnote.

$\ddagger$ Values refer to average antibody $\mathrm{N}$ per $\mathrm{ml}$ serum with pool of all rabbits immunized unless indicated otherwise in footnote.

$\$$ Values refer to average PCA titers only of positive sera.

|| Sera not analyzed quantitatively because agar diffusion (Preer) indicated no precipitin reactions.

If Values refer to antibody $\mathrm{N}$ per $\mathrm{ml}$ serum of pool consisting of the number of sera indicated in parenthesis.

** For values see Table III

$\ddagger$ Pool consisted only of weeks 2 and 3 bleedings.

Table III. It is apparent that with repeated immunization there was some increase in the amount of protein precipitated by LA. The type of "precipitin" reaction noted with some of the rabbit sera is shown in Fig. 1. In the course of analyzing the precipitates, it was noted that the size of the precipitate diminished with repeated washings in the cold $\left(4^{\circ} \mathrm{C}\right)$ with $0.15 \mathrm{M} \mathrm{NaCl}, \mathrm{pH} 7.5$. Because of the nature of the precipitation of $\mathrm{L}_{70} \mathrm{~A}_{30}$ with the sera, i.e. a very rapid flocculation, the flaky nature of the precipitate and the large excess of $\mathrm{L}_{70} \mathrm{~A}_{30}$ needed to dissolve the specific precipitate, varying amounts of $\mathrm{L}_{70} \mathrm{~A}_{30}$ were added to several rabbit, guinea pig, and human sera. The data presented 
in Table IV indicate that many normal sera precipitate with $\mathrm{L}_{70} \mathrm{~A}_{80}$. The precipitated material had an absorption spectrum similar to that of serum albumin or serum $\gamma$-globulin. Because of the known precipitation behavior of polylysine with serum proteins, its precipitation was compared with $\mathrm{L}_{70} \mathrm{~A}_{30}$. On a weight basis, LA precipitated more protein than poly $L$ from an anti-LA serum. Addition of poly $\mathrm{L}$ to a serum absorbed with $\mathrm{L}_{70} \mathrm{~A}_{30}$ or the addition of $\mathrm{I}_{70} \mathrm{~A}_{30}$ to a serum absorbed with poly $\mathrm{L}$ precipitated the same amounts of protein as when the polymers (poly $\mathrm{L}$ and $\mathrm{L}_{70} \mathrm{~A}_{30}$ ) were added to the same unabsorbed serum. To further characterize the protein precipitated by $\mathrm{L}_{70} \mathrm{~A}_{30}$,

TABLE III

Effect of Addition of $L_{70} A_{30}$ to Rabbit "Antiserum" upon Precipilation of Serum Proteins

\begin{tabular}{c|c|c|c|c}
\hline \multirow{2}{*}{ Rabbit No. } & Course No. & \multicolumn{3}{|c}{ LA added per ml serum } \\
\cline { 2 - 4 } $1-38$ & & $3.1 \mu \mathrm{g} \mathrm{N}$ & $15.5 \mu \mathrm{g} \mathrm{N}$ & $26.2 \mu \mathrm{g} \mathrm{N}$ \\
\hline \multirow{3}{*}{$1-42$} & I & $6.6^{*}$ & $9.0^{*}$ & $11.5^{*}$ \\
& II & 33.0 & 33.6 & 21.5 \\
& III & 31.5 & 40.7 & 45.2 \\
$1-46$ & I & 2.0 & 2.1 & 3.8 \\
& II & 11.2 & 9.6 & 10.4 \\
& III & 15.1 & 18.1 & 26.4 \\
& I & 2.0 & 3.7 & 4.0 \\
& II & 11.8 & & 21.4 \\
& III & 36.3 & 51.0 & 58.0 \\
& I & 26.9 & 29.2 & 11.8 \\
& II & 34.8 & 38.5 & 40.8 \\
& III & 22.5 & 30.2 & 42.9 \\
\hline
\end{tabular}

* $\mu \mathrm{g} \mathrm{N}$ rabbit $\gamma$-globulin equivalents precipitated.

immunoelectrophoretic studies were undertaken. Fig. 2 shows that with our own as well as with an antiserum supplied by Dr. T. J. Gill III, $\mathrm{L}_{70} \mathrm{~A}_{30}$ precipitated a protein migrating in the region of rabbit serum albumin, and no precipitate formed in the region of rabbit $\gamma$-globulin. A similar reaction was observed with purified rabbit serum albumin, Cohn fraction V.

The passive transfer to guinea pigs of up to $300 \mu \mathrm{g}$ "antibody" $\mathrm{N}$ could not sensitize the guinea pigs for passive anaphylaxis when challenged intravenously with $2 \mathrm{mg}$ of $\mathrm{L}_{70} \mathrm{~A}_{30}$.

Guinea Pigs. - None of the animals reacted against $\mathrm{G}_{90} \mathrm{~A}_{10}$, but $9 / 12$ and $4 / 7$ reacted against $\mathrm{G}_{80} \mathrm{Leu}_{20}$ and $\mathrm{G}_{75} \mathrm{~V}_{25}$ as measured by PCA reactions. The PCA titers against these polymers were $1: 500$ and 1:50 respectively. In addition, both immediate and delayed reactions were noted. The results on the immunization of guinea pigs with $\mathrm{L}_{70} \mathrm{~A}_{30}$ were also inconclusive. As indicated in Table $\mathrm{V}$, there were some immediate and delayed reactions among the 10 guinea pigs. 


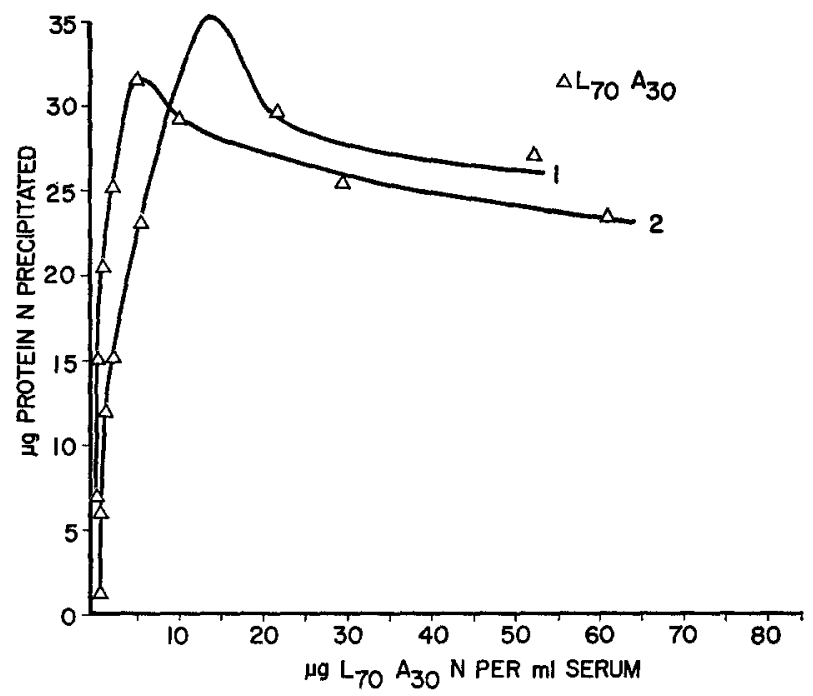

FIG. 1. Precipitation reaction between $\mathrm{L}_{70} \mathrm{~A}_{30}$ and rabbit antiserum. $I$ and 2 refer to two different serum pools.

TABLE IV

Precipitation of Protein from Sera by Addition of $L_{70} A_{30}$

\begin{tabular}{l|c}
\hline Serum & $\begin{array}{c}\text { Rabbit } \gamma \text {-globulin equivalents } \\
\text { precipitated per ml serum" }\end{array}$ \\
\hline Normal human & $\mu g N$ \\
Normal rabbit & $17.4(5)$ \\
& $8.8(12)$ \\
Immune rabbit (NZW) $\ddagger$ & $16.7(12)$ \\
Immune rabbit (Dutch) & $48.7(6)$ \\
Rabbit anti-L $\mathrm{L}_{70} \mathrm{~A}_{30}$ & $11.4(6)$ \\
Guinea pig "anti- $\mathrm{L}_{70} \mathrm{~A}_{30}$ " & $34(18) \S$ \\
Guinea pig "anti-G & $24.0(2)$ \\
\end{tabular}

* Values refer to averages of number of sera given in parenthesis. These amounts of protein were precipitated by the addition of 10 to $20 \mu \mathrm{g} \mathrm{N} \mathrm{L}{ }_{70} \mathrm{~A}_{30}$.

$\ddagger$ New Zealand white rabbits.

$\$$ Value obtained from reference 16 .

However, the gross appearance of the skin reactions was not typical. The injection of $\mathrm{L}_{70} \mathrm{~A}_{30}$ into normal guinea pigs and rabbits produced similar reactions. Even after repeated immunizations, none of the sera gave positive PCA reactions.

Terpolymers.-Previous studies dealt with terpolymers containing 5 and 30 
mol per cent alanine. The terpolymers in this study consisted of glutamic acid and lysine present in a 60:40 ratio, but containing increasing amounts of alanine; i.e., 10, 20, or $60 \mathrm{~mol}$ per cent of alanine. The data obtained on the immune responses are presented in Table II. GLA10 was a more effective

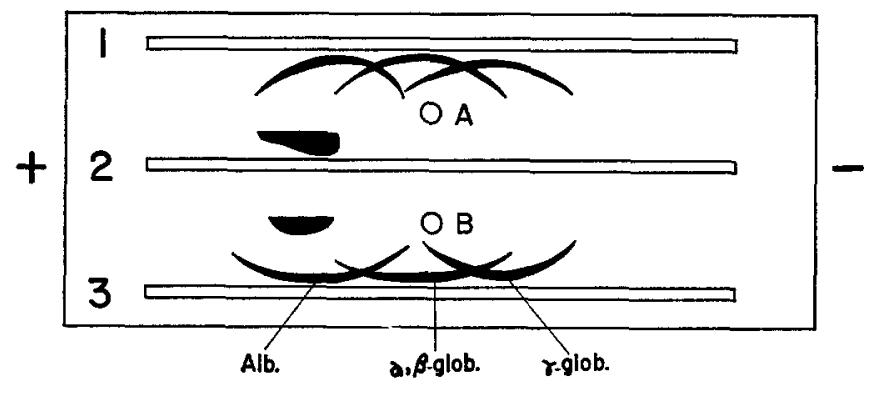

FIG. 2. Schematic diagram of immunoelectrophoretic patterns of reactions of sheep antirabbit serum and $L_{70} A_{30}$ polymer with anti-LA sera. 1 and 3 contain sheep anti-rabbit serum;

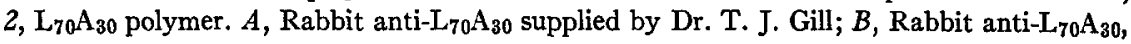
present study.

TABLE V

Immune Response in Guinea Pigs against Polymers*

\begin{tabular}{l|l|l|l}
\hline & \multicolumn{2}{|c|}{ No, of cutaneous reactions } & PCA reactions \\
\cline { 2 - 3 } & Immediate & Delayed & \\
\hline $\mathrm{G}_{90} \mathrm{~A}_{10}$ & $0 / 12$ & $0 / 12$ & 0 \\
$\mathrm{G}_{75} \mathrm{~V}_{25}$ & $4 / 7$ & $3 / 7$ & $4(1: 50)$ \\
$\mathrm{G}_{80} \mathrm{Leu}_{20}$ & $9 / 12$ & $5 / 12$ & $9(1: 500)$ \\
$\mathrm{L}_{70} \mathrm{~A}_{30}$ & $4 / 12$ & $6 / 12$ & 0 \\
$\mathrm{G}_{60} \mathrm{~A}_{40}$ & $4 / 21$ & $6 / 21$ & $4(1: 10)$ \\
\hline
\end{tabular}

* Values refer to responses after second immunization.

¥ Values refer to number of sera giving positive PCA reaction. Values in parenthesis refer to PCA titer.

antigen than GLA5 as measured by the total number of reactors, time of appearance of antibody and average antibody level after repeated immunizations. GLA20 was a still more effective immunogen than GLA10 and resembled the extent of the responses noted in the past against GLA30. Whereas 10/12 animals had antibodies detectable (PCA), against GLA20 by the first week after the first immunization, only $1 / 12$ rabbits injected with GLA10 had reacted at this time, but 6 had reacted by the third week. However, 1 week after the second injection of GLA10 in adjuvant 11/12 animals had reacted. The average levels of antibody after the third course of immunization produced 
in response to GLA10 approached the levels against GLA20. These levels were in the range of the responses noted previously against GLA30. With GLA60, which contained the maximum amount of alanine which could be introduced into the polymer and retain water solubility, the results indicate that this polymer was as good an immunogen as GLA20 and GLA30.

\section{DISCUSSION}

This report is one of a series dealing with studies aimed at describing some of the parameters determining immunogenicity of synthetic random polymers of $\alpha$-amino acids.

In our previous findings (13), as well as those of others $(14,15)$, it was shown that homopolymers are not immunogenic, but antigenicity begins with a random copolymer consisting of at least two amino acids (i.e. $\mathrm{G}_{60} \mathrm{~L}_{10}$ ). From the results presented in this report, it is evident that the proportion of these two amino acids (i.e. glutamic acid and alanine) present in the copolymer is of great importance and that copolymers having almost equal amounts of the two amino acids are very good immunogens. In our hands, $\mathrm{G}_{60} \mathrm{~A}_{40}$ and $\mathrm{G}_{40} \mathrm{~A}_{60}$ were exceedingly better than $\mathrm{G}_{75} \mathrm{~A}_{25}$ in producing responses in rabbits. Gill and Matthews reported that $2 / 8$ rabbits responded against $\mathrm{G}_{70} \mathrm{~A}_{30}$ with an average response of $15 \mu \mathrm{g} \mathrm{Ab} \mathrm{N} / \mathrm{ml}(16)$.

It is of importance to note that any discussion of immunogenicity of a polymer must be in reference to a particular species. Although $\mathrm{G}_{60} \mathrm{~A}_{\mathbf{4} 0}$ was an effective antigen in rabbits (3), this did not obtain in guinea pigs (6) or mice (9). In fact, the polymers $\mathrm{G}_{60} \mathrm{~A}_{40}$ and $\mathrm{G}_{60} \mathrm{~L}_{40}$ have been found not to be immunogenic in mice in contrast to terpolymers of glutamic acid, lysine, and alanine (9). Also, the polymers $\mathrm{G}_{75} \mathrm{~V}_{25}$ and $\mathrm{G}_{80} \mathrm{Leu}_{20}$ which produced poor responses in rabbits were fair antigens in guinea pigs. The reasons for these findings are not known. The enhanced immunogenicity of $\mathrm{G}_{60} \mathrm{~A}_{40}$ and $\mathrm{G}_{40} \mathrm{~A}_{60}$ may be related to the formation of more random sequences of glutamic acid and alanine in these polymers than in $\mathrm{G}_{90} \mathrm{~A}_{10}$ and $\mathrm{G}_{75} \mathrm{~A}_{25}$. These latter polymers are more related to the non-antigenic homopolymer polyglutamic acid. Although a significant amount of the specificity in the glutamic acid-alanine polymers resides in glutamic acid sequences (5), it is apparent that $\mathrm{G}_{60} \mathrm{~A}_{40}$ and $\mathrm{G}_{40} \mathrm{~A}_{60}$ have properties which allow them to be degraded to the requisite antigenic unit before elimination. Polyglutamic acid may not be antigenic because it is degraded too rapidly or has too high a net negative charge for entering the antibody forming cells. The differences in responses among rabbits and guinea pigs may be related to differences in the ability of cellular enzymes to degrade the glutamic acid-valine and glutamic acid-leucine polymers. The importance of metabolizibility of a polymer and its immunogenicity was shown recently with polymers of $\mathrm{D}$-amino acids. Polymers of the $\alpha$-amino acids glutamic acid, alanine and tyrosine of $\mathbf{D}$ optical configurations, either, free (17) or coupled to the haptene arsanilic acid, are not immunogenic in rabbits or guinea pigs (18) in contrast to similar polymers made of L-amino acids. These observations support the idea that metabolism of the antigen is necessary to form the immunogenic fragment carrying the antigenic determinant (19-23). Studies underway on the action of rabbit and guinea pig "cathepsins" on these various polymers may contribute more to an 
understanding of the problem. It has been reported that alanyl containing peptides are more susceptible to hydrolysis than those containing valine or leucine (24).

The copolymers discussed so far all contained glutamic acid which, at physiological $\mathrm{pH}$, is predominantly negatively charged. In order to study the role of charge in immunogenicity, the positively charged polymer $\mathrm{L}_{70} \mathrm{~A}_{30}$ was studied. Although Gill and Matthews (16) have reported that this latter polymer is antigenic in 17/18 rabbits (average response $34 \mu \mathrm{g}$ antibody $\mathrm{N}$ per $\mathrm{ml}$ serum), our observations cannot confirm these findings. In spite of the fact that with some of the hyperimmune rabbits, there was an increase in "anti-LA" after immunization, our results indicate that $\mathrm{L}_{70} \mathrm{~A}_{30}$ is precipitating protein which has the mobility of albumin. In addition, the immediate formation of a precipitate upon the addition of LA, the nature of the precipitin curve, the behavior of the precipitate during washing, the diffculty of redissolving the precipitate, the inability of rabbit "antisera" to cause systemic anaphylaxis in guinea pigs, elc., all support the idea that $\mathrm{L}_{70} A_{80}$, if immunogenic at all, is a very poor antigen. It is doubtful that after repeated immunizations (complete Freund's adjuvant), if $\mathrm{L}_{70} \mathrm{~A}_{30}$ were antigenic, no $7 \mathrm{~S} \gamma$-globulin would be formed. Even if 5 to 10 per cent of the total protein precipitated by LA in either our rabbit sera or the two supplied by Dr. Gill containing $50 \mu \mathrm{g}$ antibody $\mathrm{N}$ were $7 \mathrm{~S} \gamma$-globulin, positive anaphylactic reaction should have been noted. Additional findings that led us to question the precipitation of $\mathrm{L}_{70} \mathrm{~A}_{30}$ were that when 0.2 to $5 \mu \mathrm{g} \mathrm{N}$ was added to a $1: 10$ dilution of $\mathrm{G}_{42} \mathrm{~L}_{28} \mathrm{~A}_{30}$ antiserum containing $15 \mu \mathrm{g}$ antibody $\mathrm{N}$ per $\mathrm{ml}, 1$ to $5 \mu \mathrm{g} \mathrm{N}$ was precipitated. The addition of the homologous antigen to the supernatant indicated that no specific antibody was removed. Also, when $\mathrm{L}_{70} \mathrm{~A}_{30}$ was added to absorbed anti- $\mathrm{G}_{42} \mathrm{~L}_{28} \mathrm{~A}_{30}$ sera, the same amount of protein precipitated as before the antibody was absorbed. A possible explanation for the non-immunogenicity of $\mathrm{L}_{70} \mathrm{~A}_{30}$ may be related to the high lysine content of the polymer which allows it to be degraded very rapidly to units too small to act as antibody formation initiators. However, many other polymers studied which had lysine in them were antigenic. It is also of interest in this regard that although a DNP polylysine was antigenic in some guinea pigs, this derivative was not antigenic in rabbits (23).

Immunogenicity does not appear to be related directly to the presence of lysyl groups. In fact, the presence of lysyl groups seems to have decreased the immunogenicity of glutamic acid-containing polymers by interacting with glutamyl residues which are the major determinants of antigenicity. By introducing alanyl groups into the terpolymers which have glutamic acid and lysine present in a 60:40 ratio, the interactions between glutamic acid and lysine groupings are decreased and antigenicity appears to have been enhanced. This may explain why the terpolymers having more than 5 to $10 \mathrm{~mol}$ per cent alanine are better antigens than GL or GLA5. It has also been observed that the $\alpha$-helix content of the terpolymers increased as the ala concentration increased (25). However, what contribution helical content may make towards immunogenicity is also not known.

Preliminary experiments have indicated that when $\mathrm{G}_{60} \mathrm{~L}_{40}$ is deaminated, the derivative is much more antigenic in rabbits than the original copolymer. We 
have attributed this to the breaking of forces of interaction between glutamyl$\mathrm{COO}^{-}$, and lysyl epsilon- $\mathrm{NH}_{3}^{+}$, groups by the conversion of the latter groups to $-\mathrm{OH}$. The reaction of deaminated $\mathrm{G}_{60} \mathrm{~L}_{50}$, but not $\mathrm{G}_{60} \mathrm{~L}_{40}$ with anti- $\mathrm{G}_{60} \mathrm{~A}_{40}$ sera, and the reaction of $\mathrm{G}_{60} \mathrm{~A}_{40}$ with antisera against deaminated $\mathrm{G}_{60} \mathrm{~L}_{40}$ attest to the involvement of carboxylate groups in the antigenic determinants of these copolymers. The recent findings of McCarthy on the non-antigenicity of a glutamamide:alanine $(55: 45)$ copolymer may also be related to this concept (26).

\section{SUMMARY}

A new group of synthetic random polymers of $\alpha$-L-amino acids has been studied for immunogenicity. With the glutamic acid and alanine copolymers, those consisting of almost equimolar amounts of the two $\left(\mathrm{G}_{60} \mathrm{~A}_{40}\right.$ and $\left.\mathrm{G}_{40} \mathrm{~A}_{60}\right)$ were effective antigens in rabbits whereas those with higher glutamic acid contents $\left(\mathrm{G}_{76} \mathrm{~A}_{25}, \mathrm{G}_{90} \mathrm{~A}_{10}\right)$ were poor antigens. The substitution of alanine by valine or leucine $\left(\mathrm{G}_{75} \mathrm{~V}_{25}\right.$ and $\left.\mathrm{G}_{80} \mathrm{Leu}_{20}\right)$ produced copolymers which were poor antigens in rabbits but effective in guinea pigs. $\mathrm{L}_{70} \mathrm{~A}_{30}$, although capable of "non-specifically" precipitating serum proteins, was shown not to be antigenic in either rabbits or guinea pigs. The introduction of alanine into glutamic acid and lysine polymers (GLA series) enhanced the immunogenicity of the terpolymers, i.e., GLA30 > GLA20 > GLA10 > GL. The mechanism by which this may be accomplished is discussed as possibly being related to the reduction of the interactions between glutamyl and lysyl residues which allows the carboxyl groups to act as strong immunogenic determinants.

The authors wish to acknowledge the technical assistance of Miss A. Lee, Miss L. Makulinski, and Mrs. P. Lee.

\section{BIBLIOGRAPHY}

1. Maurer, P. H., Subrahmanyam, D., Katchalski, E., and Blout, E. R., Antigenicity of polypeptides (poly alpha amino acids), J. Immunol., 1959, 83, 193.

2. Maurer, P. H., Antigenicity of polypeptides (poly alpha amino acids). II, $J$. Immunol., 1962, 88, 330.

3. Maurer, P. H., Gerulat, B. F., and Pinchuck, P., Antigenicity of polypeptides (poly alpha amino acids). V. Studies in rabbits, I. Immunol., 1963, 90, 381.

4. Maurer, P. H., Gerulat, B. F., and Pinchuck, P., Antigenicity of polypeptides (poly alpha amino acids). VI. Studies in rabbits, J. Immunol., 1963, 90, 388.

5. Maurer, P. H., Gerulat, B. F., and Pinchuck, P., Antigenicity of polypeptides (poly alpha amino acids). XI. Quantitative relationships among polymers and rabbit antisera, J. Biol. Chem., 1964, 239, 922.

6. Maurer, P. H., Antigenicity of polypeptides (poly alpha amino acids). IV. Studies in guinea pigs, J. Immunol., 1963, 90, 493.

7. Maurer, P. H., and Cashman, T., Antigenicity of polypeptides (poly alpha amino acids). VIII. Studies in guinea pigs, J. Immunol., 1963, 90, 393. 
8. Maurer, P. H., Gerulat, B. F., and Pinchuck, P., Antigenicity of polypeptides (poly alpha amino acids). VII. Studies in humans, J. Exp. Med., 1963, 116, 521.

9. Pinchuck, P., and Maurer, P. H., unpublished observations.

10. Ovary, Z., Immediate reactions in the skin of experimental animals provoked by antigen antibody interaction, Progr. Allergy, 1958, 5, 459.

11. Preer, J. R., Jr., A quantitative study of a technique of double diffusion in agar, J. Immunol., 1956, 77, 52.

12. Grabar, P., and Burtin, P., L'analyse immunoélectrophorétique; ses applications aux milieux biologiques humaines, Paris, Maison et Cie, 1960.

13. Maurer, P. H., Attempts to produce antibodies to a preparation of polyglutamic acid, Proc. Soc. Exp. Biol. and Med., 1957, 96, 394.

14. Buchanan-Davidson, D. J., Stahmann, M. A., Lapresle, C., and Grabar, P., Immunochemistry of synthetic polypeptides and polypeptidyl proteins. III. Antigenicity of the synthetic polypeptides, $J$. Immunol., 1959, 83, 552.

15. Gill, T. J., and Doty, P., Studies on synthetic polypeptide antigens. II. The immunochemical properties of a group of linear synthetic polypeptides, $J$. Biol. Chem., 1961, 236, 2677.

16. Gill, T. J., and Matthews, L. S., Studies on synthetic polypeptide antigens. IX. The antigenicity of a new group of linear synthetic polypeptides, J. Biol. Chem., 1963, 238, 1373.

17. Maurer, P. H., Antigenicity of polypeptides (poly alpha amino acids). X. Studies with polymers of D-amino acids, Proc. Soc. Exp. Biol. and Med., 1963, 113, 553.

18. Benacerraf, B., Ojeda, A., and Maurer, P. H., Studies on artificial antigens. II. The antigenicity in guinea pigs of arsanilic acid conjugates of copolymers of $D$ or L- $\alpha$-amino acids, $J$. Exp. Med., 1963, 118, 945.

19. Garvey, J. S., and Campbell, D. H., The retention of $\mathrm{S}^{35}$-labeled bovine serum albumin in normal and immunized rabbit liver tissue, J. Exp. Med., 1957, 105, 361.

20. Rittenberg, M., and Nelson, E. L., Macrophages, nucleic acid and the induction of antibody formation, Am. Naturalist, 1960, 94, 321.

21. Fishman, M., Antibody formation in vitro, J. Exp. Med., 1961, 114, 837.

22. Fishman, M., and Adler, F. L., Antibody formation initiated in vitro. II. Antibody synthesis in $\mathrm{x}$-irradiated recipients of diffusion chambers containing nucleic acid derived from macrophages incubated with antigen, J. Exp. Med., 1963, $117,595$.

23. Kantor, F. S., Ojeda, A., and Benacerraf, B., Studies on artificial antigens. I. The antigenicity of DNP-polylysine and DNP copolymer of lysine and glutamic acid in guinea pigs, J. Exp. Med., 1963, 117, 55.

24. Sanger, F., The arrangement of amino acids in proteins, Advances Protein Chem., 1952, 7, 1.

25. Blout, E. R., and Simmons, E., personal communication.

26. McCarthy, R., personal communication. 